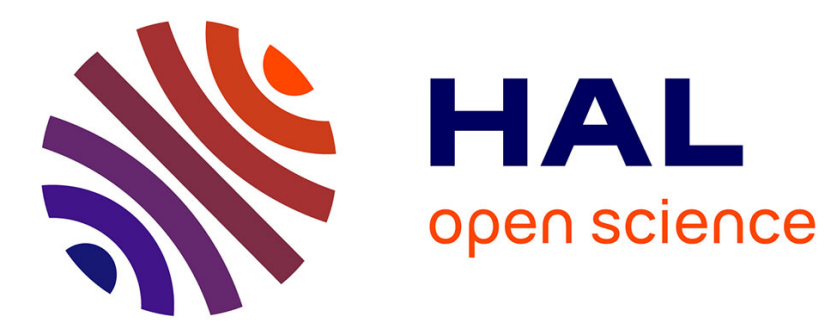

\title{
Heterometallic coordination polymers based on homo- and heteroleptic Au(III) dithiolene complexes
}

Damien Bechu, Alexandru Mihai Petre, Mir Wais Hosseini, Stephane Baudron

\section{To cite this version:}

Damien Bechu, Alexandru Mihai Petre, Mir Wais Hosseini, Stephane Baudron. Heterometallic coordination polymers based on homo- and heteroleptic $\mathrm{Au}$ (III) dithiolene complexes. CrystEngComm, 2020, 22 (35), pp.5760-5767. 10.1039/D0CE01090A . hal-02944375

\section{HAL Id: hal-02944375 \\ https://hal.science/hal-02944375}

Submitted on 21 Sep 2020

HAL is a multi-disciplinary open access archive for the deposit and dissemination of scientific research documents, whether they are published or not. The documents may come from teaching and research institutions in France or abroad, or from public or private research centers.
L'archive ouverte pluridisciplinaire HAL, est destinée au dépôt et à la diffusion de documents scientifiques de niveau recherche, publiés ou non, émanant des établissements d'enseignement et de recherche français ou étrangers, des laboratoires publics ou privés. 


\title{
Heterometallic coordination polymers based on homo- and heteroleptic Au(III) dithiolene complexes
}

\author{
Damien Bechu, Alexandru Mihai Petre, Mir Wais Hosseini* and Stéphane A. Baudron* \\ Université de Strasbourg, CNRS, CMC UMR 7140, 4 rue Blaise Pascal, F-67000, Strasbourg, \\ France.Fax: 33 368851325;Tel: 33 368856711; E-mail: hosseini@unistra.fr, \\ sbaudron@unistra.fr
}

Two novel hetero- and homoleptic Au(III) complexes based on a dithiolene ligand bearing two 4-thiopyridyl groups have been designed, synthesized and characterized in solution and in the crystalline state. These species have been employed as metalloligands, or metallatectons, for the elaboration of heterometallic coordination polymers upon assembly with $\mathrm{M}(\mathrm{NCS})_{2}$ salts (M $=\mathrm{Mn}, \mathrm{Co}, \mathrm{Cd})$ and $\mathrm{Co}\left(\mathrm{N}(\mathrm{CN})_{2}\right)_{2}$ respectively. Upon combination of the neutral heteroleptic complex comprising a cyclometallating benzo[h]quinoline fragment and the mononuclear $\mathrm{Mn}(\mathrm{NCS})_{2}$ and $\mathrm{Co}(\mathrm{NCS})_{2}$ nodes, one-dimensional coordination networks were obtained. They feature pendant heteroleptic complexes that stack centrosymmetrically in the crystalline state leading to an interdigitated system, analogous to what has been reported with the parent EDTTTF derivative. With $\mathrm{Cd}(\mathrm{NCS})_{2}$, the inorganic moieties form a two-dimensional ruffled layer with bridging thiocyanate anions, while the $\mathrm{Au}(\mathrm{III})$ complexes occupy the remaining apical positions of the $\mathrm{Cd}$ (II) centers. This leads to a stacking of the heteroleptic species. With the homoleptic complex, monoanionic analogue of a symmetrical TTF, a two-dimensional coordination network was obtained by combination with $\mathrm{Co}\left(\mathrm{N}(\mathrm{CN})_{2}\right)_{2}$, featuring one dimensional $\left[\mathrm{Co}\left(\mathrm{N}(\mathrm{CN})_{2}\right)\right]_{\alpha}$ chains. These networks have been characterized in the crystalline state by X-ray diffraction and represent, to the best of our knowledge, the first heterometallic coordination polymers based on $\mathrm{Au}(\mathrm{III})$ dithiolene complexes and transition metal cations.

\section{Introduction}

Endowed with unique electrochemical and optical properties, metal dithiolene complexes represent an important class of compounds with a diversity of applications in material science, catalysis or biology, for example. ${ }^{1}$ A particular attention has been given to the use of these complexes as metalloligands, ${ }^{2}$ or metallatectons, ${ }^{3}$ for the preparation of coordination polymers (CPs) and metal-organic frameworks (MOFs) upon assembly with alkali ${ }^{4}$ or transition metal cations. ${ }^{5}$ In particular, $\mathrm{Ni}(\mathrm{II}), \mathrm{Cu}$ (II) and $\mathrm{Pd}(\mathrm{II})$ complexes incorporating a dithiolene ligand appended with peripheral nitrogen-based coordinating units have been exploited for such purposes. ${ }^{1 \mathrm{~h}}$ While a variety of $\mathrm{Au}$ metalloligands have been described in the literature, ${ }^{6} \mathrm{Au}$ dithiolene complexes remain underexplored for the construction of heterometallic CPs and MOFs. ${ }^{4 f, 4 i}$ This is surprising given that crystalline networks built from the self-assembly of $\mathrm{Au}$ (III) dithiolene complexes bearing hydrogen or halogen bonding donor/acceptor units have been otherwise reported, ${ }^{7}$ and that several complexes functionalized with pyridine moieties, hence potential metalloligands, have been described. ${ }^{8}$ Furthermore, Au dithiolene complexes have been demonstrated to allow the formation of molecular conductors ${ }^{9}$ and can bear appealing optical properties. ${ }^{10}$ 

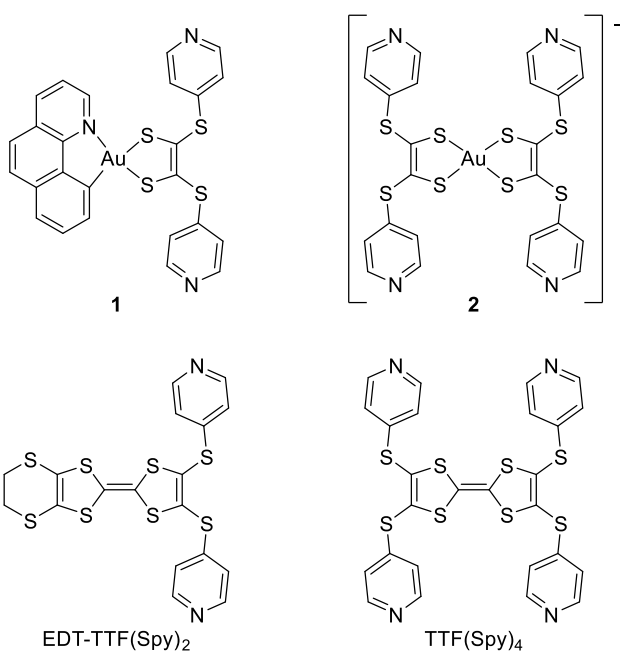

Scheme 1 Parallel between the reported EDT-TTF(Spy $)_{2}$ and TTF(Spy) 4 and the target $\mathrm{Au}(\mathrm{III})$ hetero- and homoleptic dithiolene complexes $\mathbf{1}$ and $\mathbf{2}$.

Recently, we have reported the novel thiopyridine-appended symmetrical and dissymmetrical tetrathiafulvalene derivatives $\operatorname{TTF}(\mathrm{Spy})_{4}$ and $\operatorname{EDT}-\mathrm{TTF}(\mathrm{Spy})_{2}$ (Scheme 1) and their CPs upon association with metal salts, some of them featuring electronic conductivity following surface oxidation with iodine. ${ }^{11}$ Owing to the isolobal analogy between tetrathiafulvalene derivatives and dithiolene complexes, it appeared interesting to investigate the possibility to develop metalorganic analogues of these thiopyridine-appended TTFs and study their ability to form CPs. Thus, novel hetero- and homo-leptic complexes $\mathbf{1}$ and $\mathbf{2}$ respectively (Scheme 1) have been considered in the context of this work. The heteroleptic compound $\mathbf{1}$ has been designed to parallel EDT-TTF(Spy) 2 , hence comprising a dithiolene fragment functionalized with two thiopyridyl groups and a cyclometallated $\mathrm{Au}(\mathrm{III}) / \mathrm{benzo}[\mathrm{h}]$ quinoline moiety. The rationale behind the choice of this latter unit was, on one hand, to form a neutral complex and, on the other hand, to introduce an aromatic fragment prone to stacking, potentially leading to interdigitation as observed in the CPs based on EDT-TTF(Spy) $2 .{ }^{11 \mathrm{~b}}$ The monoanionic homoleptic complex 2 bears the same symmetrical structure as for $\operatorname{TTF}(\operatorname{Spy})_{4}$, but differs in its charge. In this study, we report the synthesis and characterization of the title complexes $\mathbf{1}$ and 2 and their assembly with metal salts towards the formation of heterometallic coordination networks that have been characterized in the crystalline state.

\section{Results and discussion}

Complex 1 was synthesized in $29 \%$ yield by reaction of the target dithiolene, generated in situ by treatment of dithiolone $3^{11 a}$ with sodium methanolate, with the cyclometallated complex $\mathbf{4}$, prepared as described. ${ }^{12}$ Homoleptic complex $\mathbf{2}$ was prepared in $22 \%$ yield as a tetraphenylphosphonium salt by reaction of the dithiolene with $\mathrm{KAuBr}_{4}$ followed by cation metathesis (Fig. 1). Compounds $\mathbf{1}$ and $\left(\mathrm{Ph}_{4} \mathrm{P}\right) \mathbf{2}$ have been characterized in solution by UVvisible spectroscopy and cyclic voltammetry. For $\mathbf{1}$ in DMF, a weak absorption band around $400 \mathrm{~nm}$ corresponding to a MLCT and a more intense band around $310 \mathrm{~nm}$ associated to the cyclometallated fragment were observed, as described for other cyclometallated gold dithiolene complexes. ${ }^{13}$ For $\left(\mathrm{Ph}_{4} \mathrm{P}\right) 2$ in DMF, an intense band at $340 \mathrm{~nm}$ was observed that may be attributed to either LMCT or $\pi-\pi^{*}$ transition, as reported for similar types of complexes (Fig. 
ESI5). The electrochemical properties of 1 have been investigated by cyclic voltammetry in DMF, no well resolved electrochemical processes over the potential window could be detected. For $\left(\mathrm{Ph}_{4} \mathrm{P}\right) 2$ in $\mathrm{MeCN}$, a quasi-reversible reduction was observed at $E=-1.79 \mathrm{~V} v s \mathrm{Fc} / \mathrm{Fc}^{+}(\Delta \mathrm{E}$ $=0.14 \mathrm{~V}$ ) associated with the $\mathbf{2}^{-} / \mathbf{2}^{2-}$ redox couple. ${ }^{8}$ In oxidation, no reversible redox wave associated with the $2^{0} / \mathbf{2}^{-}$couple could be clearly observed; only irreversible processes leading to decomposition products that afforded complex voltammograms upon further cycling.

Compounds 1, $\left(\mathrm{Ph}_{4} \mathrm{P}\right) \mathbf{2}$ and $\mathbf{3}$ have been also characterized by single-crystal $\mathrm{X}$-Ray diffraction (Fig. 1 left, Tables 1 and 2). Starting compound $\mathbf{3}$ crystallizes in the orthorhombic Pnma space group and shows an arrangement of the two thiopyridyl groups on the same side of the dithiolone core, in a so-called $\alpha_{2}$ fashion, as observed for the corresponding TTF derivatives. ${ }^{11}$ A similar $\alpha_{2}$ arrangement of the pyridine units is present in the structure of complex 1 that crystallizes in the monoclinic $C 2 / c$ space group. The $\mathrm{Au}(\mathrm{III})$ cation is in a square planar environment, bound to the dithiolene chelate and to the cyclometallating benzo[h]quinoline ligand with an Au-C distance slightly shorter than the Au-N one (Table 1), as reported for other analogous species. ${ }^{13}$ In the crystal, the complexes stack in a centrosymmetric fashion with the shortest Au-Au distance of 3.713(1) $\AA$. Salt $\left(\mathrm{Ph}_{4} \mathrm{P}\right) 2$ crystallizes in the monoclinic $C 2 / c$ space group. In this structure, the $\mathrm{Au}(\mathrm{III})$ center adopts a square planar geometry and is coordinated to two dithiolene dianionic chelates with Au-S distances as commonly observed for this type of homoleptic complexes (Table 1). ${ }^{8,9}$ The thiopyridyl groups alternate above and below the mean $\mathrm{AuS}_{4}$ plane; the complex 2 can thus be described as adopting a $\alpha \beta \alpha \beta$ conformation in analogy with the $\operatorname{TTF}(\operatorname{Spy})_{4}$ compound. ${ }^{11 a}$ In the crystal, the monoanionic complexes are separated by the tetraphenylphosphonium anions leading to a long Au-Au distance (Table 1).

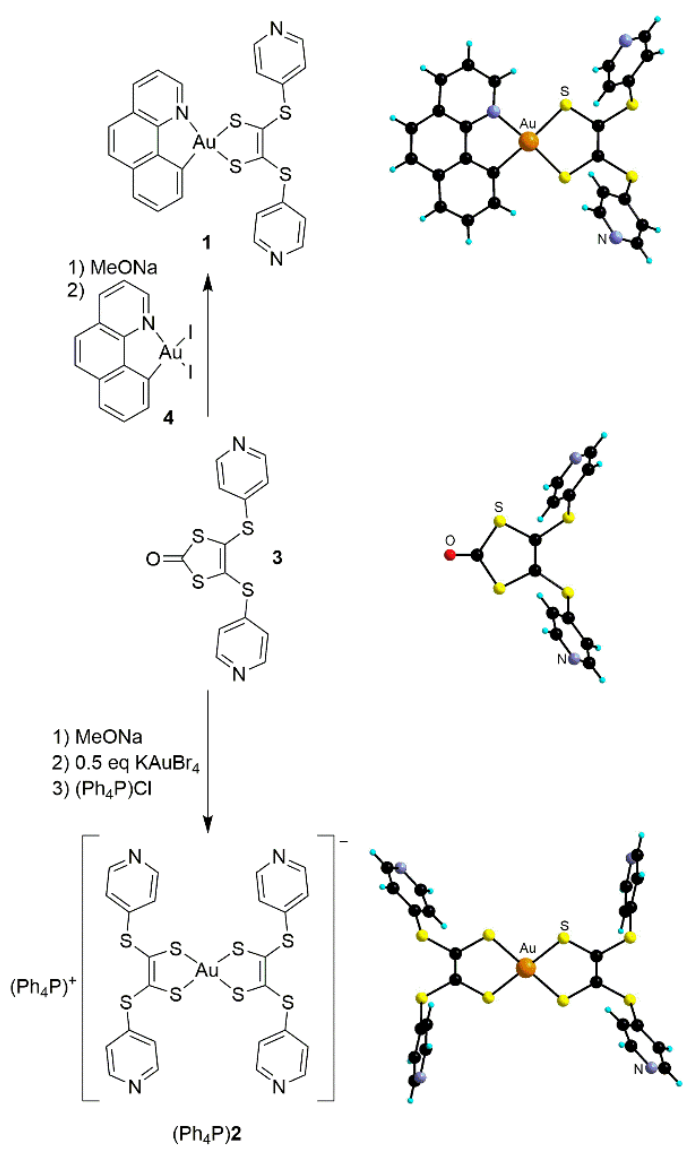

Fig. 1 Synthesis of $\mathrm{Au}(\mathrm{III})$ complexes 1 and $\left(\mathrm{Ph}_{4} \mathrm{P}\right) \mathbf{2}$ (left) and crystal structures of 1-3 (right). 
Table 1 Selected bond distances $(\AA)$ for complexes 1 and 2 and networks 5-8.

\begin{tabular}{llllll} 
& $\mathrm{Au}-\mathrm{C}$ & $\mathrm{Au}-\mathrm{N}$ & $\mathrm{Au}-\mathrm{S}$ & $\mathrm{Au}-\mathrm{Au}$ & $\mathrm{M}-\mathrm{N}_{\mathrm{py}}$ \\
\hline $\mathbf{1}$ & $2.070(3)$ & $2.074(3)$ & $2.2894(9)$ & $3.713(1)$ & - \\
$\mathbf{2}$ & - & - & $2.3168(7)$ & $7.319(3)$ & - \\
$\mathbf{5}$ & $2.064(3)$ & $2.070(3)$ & $2.2950(9)$ & $4.087(4)$ & $2.311(3)$ \\
$\mathbf{6}$ & & $2.047(9)$ & $2.295(3)$ & $3.653(3)$ & $2.185(10)$ \\
$\mathbf{7}$ & $2.076(3)$ & $2.074(3)$ & $2.2912(8)$ & $3.885(3)$ & $2.375(10)$ \\
$\mathbf{8}$ & - & - & $2.311(3)$ & $9.147(4)$ & $2.155(7)$
\end{tabular}

The preparation of coordination networks based on 1 was explored by combination with $\mathrm{M}(\mathrm{NCS})_{2}$ salts $(\mathrm{M}=\mathrm{Mn}, \mathrm{Co}, \mathrm{Cd})$, since such salts have been demonstrated to form crystalline materials with a variety of pyridyl-appended TTFs. ${ }^{11,14}$ Slow diffusion of a solution of $\mathrm{Mn}(\mathrm{NCS})_{2}(\mathrm{Py})_{4}$ in EtOH into a solution of $\mathbf{1}$ in $\mathrm{CHCl}_{3}$ led to the formation of crystals of CP $\mathbf{5}$, formulated $\left[(\mathbf{1})_{2} \mathrm{Mn}(\mathrm{NCS})_{2}\right]\left(\mathrm{CHCl}_{3}\right)_{2}$ as determined by single-crystal $\mathrm{X}$-ray diffraction (Triclinic, $P-1$, Table 2). The Mn(II) cation is in an octahedral coordination environment, bound to two apical thiocyanate anions and to four pyridyl groups of four different complexes $\mathbf{1}$ in the square base, leading to a one-dimensional network along the $b$ axis (Fig. 2). Within a chain, the $\mathrm{Mn}(\mathrm{II})$ cations are separated by $11.26 \AA$. As recently reported for the CPs [(EDT$\left.\left.\mathrm{TTF}(\mathrm{Spy})_{2}\right)_{2} \mathrm{M}(\mathrm{NCS})_{2}\right](\mathrm{M}=\mathrm{Co}, \mathrm{Fe}),{ }^{11 \mathrm{~b}}$ the pendant $\mathrm{Au}(\mathrm{III})$ complexes interdigitate along the $a$ axis (Fig. 2), this leads to the formation of channels occupied by $\mathrm{CHCl}_{3}$ molecules. Within the interdigitated stacks, the complexes are organized into centrosymmetric dimers with a lateral offset. The Au-Au distances are longer than in the structure of the free complex (Table 1). The distance between cyclometallating ligands of 3.467(6) $\AA$ suggests weak $\pi$ - $\pi$ stacking within dimers. Also, between consecutive dimers, a distance of 3.616(6) $\AA$ between the dithiolene and the benzo[h]quinoline is observed. A similar organization is observed in the crystal structure of $\mathrm{CP} \mathbf{6},\left[(\mathbf{1})_{2} \mathrm{Co}(\mathrm{NCS})_{2}\right]$ (Monoclinic, P2/m) (Fig. 2) obtained by slow diffusion of an EtOH solution of $\mathrm{Co}(\mathrm{NCS})_{2}$ (Py) 4 into a 1,1,2,2-tetrachloroethane (TCE) solution of $\mathbf{1}$. Here again, the $\mathrm{Co}$ (II) cation is in an octahedral environment with two apical thiocyanate anions and the nitrogen atom of four pyridyl groups of four different $\mathrm{Au}(\mathrm{III})$ complexes in the square base. Within the one-dimensional chain, the Co(II) centers are at a distance of 12.227(10) A. Since the complex lies on a crystallographic mirror, the carbon and nitrogen atom of the cyclometallating ligand cannot be distinguished (Table 1). Also, as a result of the higher symmetry of this crystalline material in comparison with $\mathbf{5}$, regular interdigitated stacks are observed with a shorter Au-Au distance of 3.653(3) $\AA$ and a distance between benzo[h]quinoline of $3.494 \AA$. As for 5, the interdigitation in 6 leads to the formation of channels occupied by solvent molecules. However, owing to an important disorder of the latter, the SQUEEZE command was used to account for the corresponding electron density. ${ }^{15}$ It is interesting to note the parallel between these two structures and the one of [(EDT$\left.\left.\mathrm{TTF}(\mathrm{Spy})_{2}\right)_{2} \mathrm{M}(\mathrm{NCS})_{2}\right](\mathrm{M}=\mathrm{Co}, \mathrm{Fe})$ illustrating the robustness of the strategy consisting in forming one-dimensional networks bearing pendant fragments (either a cyclometallated unit or a TTF core) prone to subsequent interdigitation. Such TTF-linker replacement by metalloligands in CPs and MOFs has been recently described. ${ }^{16}$ 

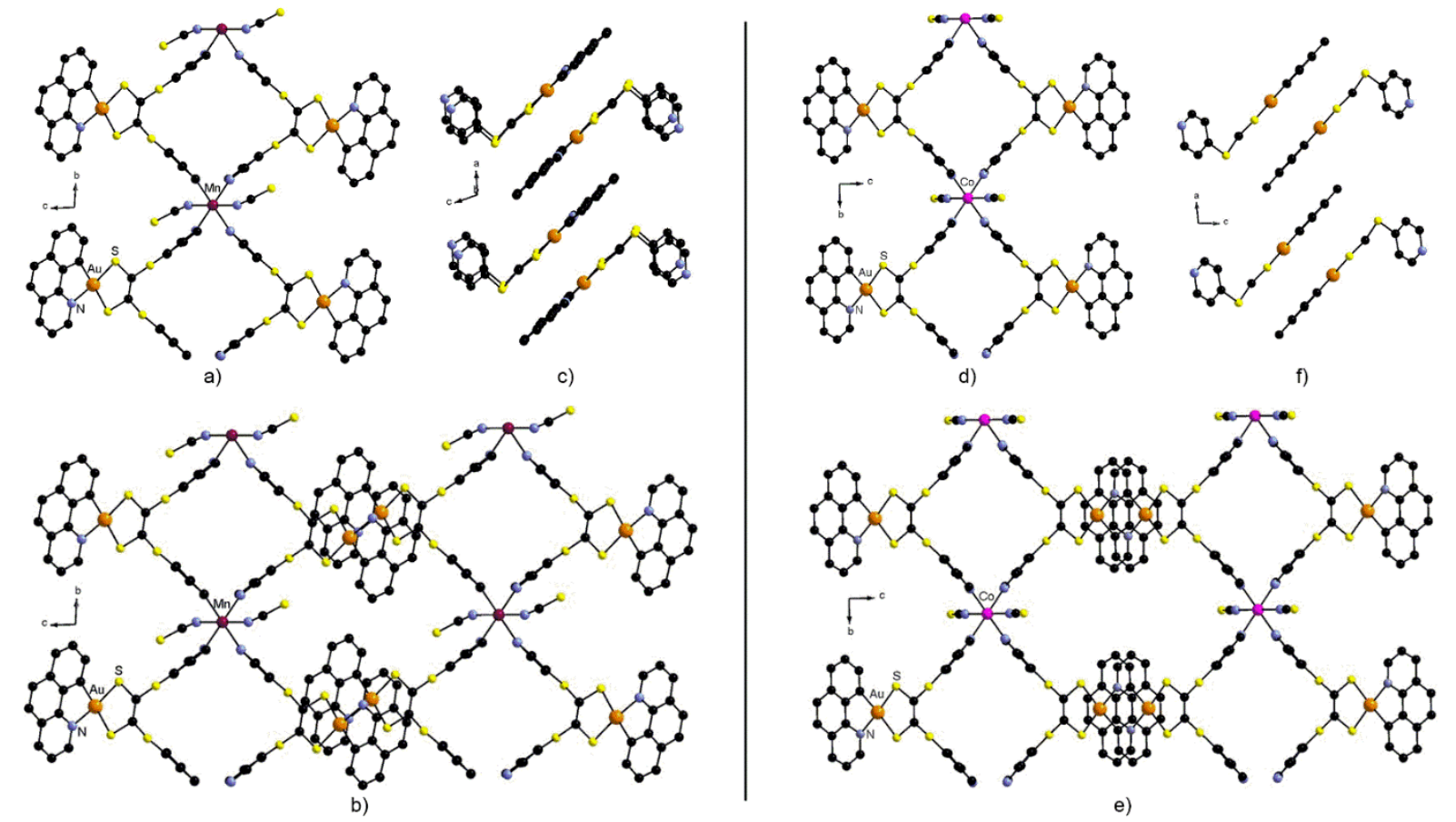

Fig. 2 Views of a portion of the one-dimensional heterometallic chains in the crystal structure of 5 (a), of the interdigitated networks (b) and of the stacking of the Au(III) heteroleptic complexes (c) and analogous representations for the crystal structure of $\mathbf{6}$ (d,e,f). Hydrogen atoms and solvent molecules have been omitted for clarity.

Upon slow diffusion of a $\mathrm{MeOH}$ solution of $\mathrm{Cd}(\mathrm{NCS})_{2}(\mathrm{Py})_{4}$ into a solution of $\mathbf{1}$ in $\mathrm{CHCl}_{3}$, crystals of different shapes formed. The batches comprised mostly orange prismatic crystals that were prone to rapid desolvation as confirmed by X-ray powder diffraction (vide infra) and for which the structure could consequently not be fully determined (Monoclinic $C 2 / \mathrm{c}$, $\mathrm{a}=$ 20.4911(11) $\left.\AA, \mathrm{b}=29.0170(16) \AA, \mathrm{c}=21.8303(11) \AA, \beta=92.557(2)^{\circ}, \mathrm{V}=12967.2 \AA^{3}\right)$. Interestingly, very few crystals of compound $\left[(\mathbf{1})_{2}\left(\mathrm{Cd}(\mathrm{NCS})_{2}\right)_{2}\right], \mathbf{7}$, could however be isolated and its structure has been determined by single-crystal X-Ray diffraction (Table 3). In this coordination polymer, the $\mathrm{Cd}(\mathrm{II})$ cations, in an octahedral environment, are coordinated to four bridging thiocyanate anions in the square base, thus forming a two-dimensional ruffled layer, and to two pyridyl groups of two different $\mathrm{Au}$ (III) complexes in the apical positions (Fig. 3). It has been reported that $\mathrm{Cd}(\mathrm{NCS})_{2}$ can adopt such an arrangement, ${ }^{17}$ and a $1 \mathrm{D}\left(\mathrm{Cd}(\mathrm{NCS})_{2}\right)_{\propto}$ chain has been observed in a $\mathrm{CP}$ based on $\mathrm{TTF}(\mathrm{Spy}) 4 .{ }^{11 \mathrm{a}}$ The heteroleptic complexes arrange in onedimensional stacks with a long Au-Au distance of 3.885(3) A combined with an Au-S contact of 3.395(1) $\AA$, shorter than the sum of the van der Waals radii. In addition, the cyclometallating fragments stack at a distance of 3.471(5) $\AA$. In 7, no interdigitation is present, unlike what is observed in the case of 5 and $\mathbf{6}$ comprising mononuclear $\mathrm{M}(\mathrm{NCS})_{2}$ nodes. 


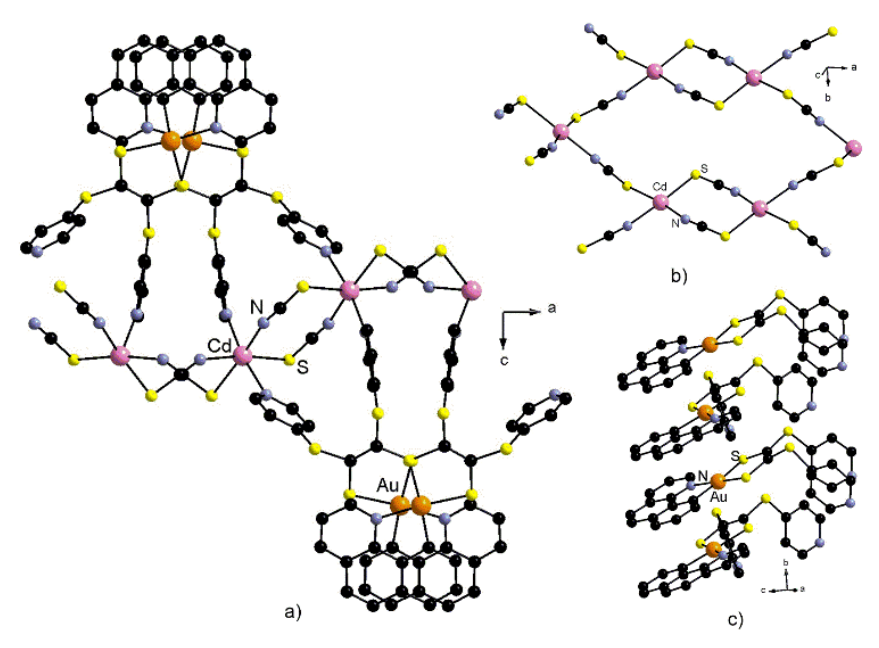

Fig. 3 View of a portion the 2D network in the crystal structure of 7 along the $a$ axis (a), of a fragment of the $2 \mathrm{D}$ inorganic $\left(\mathrm{Cd}(\mathrm{NCS})_{2}\right)_{\propto}$ layer (b) and of the stacking along the $b$ axis (c). Hydrogen atoms have been omitted for clarity.

In spite of our numerous attempts to obtain CPs based on the homoleptic complex 2 and $\mathrm{M}(\mathrm{NCS})_{2}$ salts, no crystals have been obtained so far. Other inorganic salts were considered, in particular the $\mathrm{M}\left(\mathrm{N}(\mathrm{CN})_{2}\right)_{2}$ system, for it has been shown to lead to CPs with coordinating TTFs. ${ }^{18}$ Upon slow diffusion of a $\mathrm{MeOH}$ solution of $\mathrm{Co}\left(\mathrm{N}(\mathrm{CN})_{2}\right)_{2}$ into a $\mathrm{CHCl}_{3}$ solution of $\left(\mathrm{Ph}_{4} \mathrm{P}\right) 2$, crystals of $\mathbf{8}$ formed, formulated $\left[(\mathbf{2}) \mathrm{Co}\left(\mathrm{N}(\mathrm{CN})_{2}\right)\right]$ according to the structure determination by X-ray diffraction (Table 3). In this compound, the Co(II) cation is in an octahedral environment with two dicyanamide anions in the apical positions, forming a 1D chain along the $a$ axis, and four pyridyl groups of four different $\mathrm{Au}$ (III) complexes in the square base (Fig. 4). The coordinating units are all on the same side of the dithiolene complex, organized in a $\alpha_{2} \alpha_{2}$ conformation in analogy with what has been reported for $\mathrm{TTF}(\operatorname{Spy})_{4}{ }^{11 \mathrm{a}}$ In this respect, this structure is somewhat reminiscent of the 2D CPs obtained for the latter TTF compound with $\mathrm{CdI}_{2}$. Within the 2D layers, solvent molecules are present. However, owing to the strong positional disorder, the corresponding electronic density has been removed using the SQUEEZE command. ${ }^{15}$ No stacking of the complexes is observed between the different layers and the Au-Au distances are above $9 \AA$ (Table 1).

Batches of all four CPs have been characterized by powder X-ray diffraction (see Fig. ESI 710). For CPs $\mathbf{5}, \mathbf{6}$ and $\mathbf{8}$, the powder pattern indicated that the crystalline phase is somewhat retained albeit with broad and weak diffraction peaks owing to desolvation upon exposure to air. Almost no diffraction peaks could be observed for batches obtained upon combining 1 with $\mathrm{Cd}(\mathrm{NCS})_{2}$. As discussed above, Cd-based CP 7 represents a minor phase under these conditions and the major phase appears to desolvate quickly. As a result, the optical properties and the conductivity of these four materials could unfortunately not be further explored. 


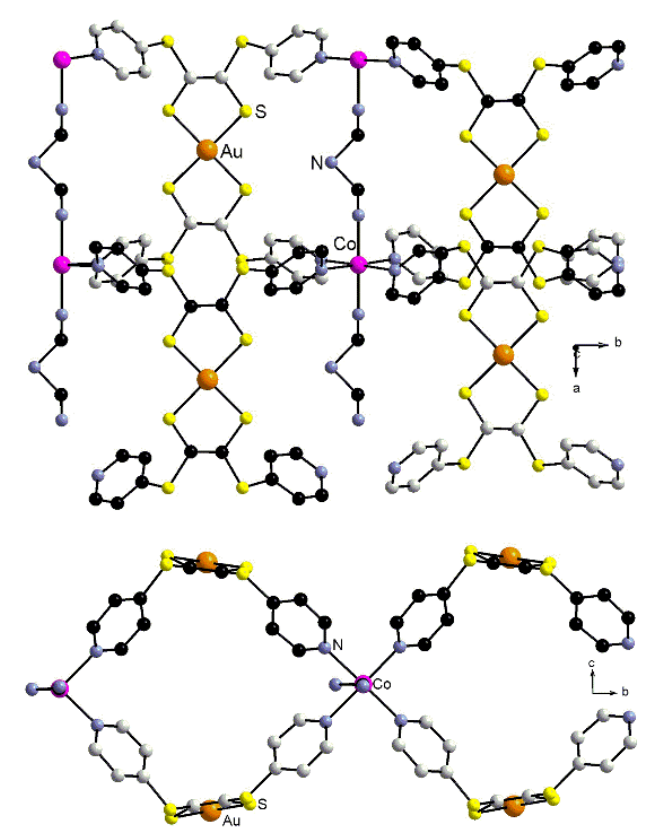

Fig. 4 Top and side views of a portion the 2D network in the crystal structure of $\mathbf{8}$. Hydrogen atoms have been omitted for clarity. The carbon atoms of the complexes in the lower part of the $2 \mathrm{D}$ network are presented in light grey for clarity.

\section{Conclusions}

Two novel homo and heteroleptic $\mathrm{Au}(\mathrm{III})$ dithiolene have been designed, prepared and characterized, as metallo-organic cousins of recently reported symmetrical and dissymmetrical TTF derivatives, respectively. These compounds bear peripheral thiopyridyl units and have thus been used as metalloligands for the elaboration of heterometallic coordination polymers. With the heteroleptic species 1 , CPs could be obtained with thiocyanate $\mathrm{M}(\mathrm{NCS})_{2}$ salts $(\mathrm{M}=\mathrm{Mn}$, $\mathrm{Co}, \mathrm{Cd})$. Interestingly with $\mathrm{M}=\mathrm{Mn}$ or $\mathrm{Co}$, interdigitated 1D networks could be obtained that bear resemblance in their organization with the CPs reported with EDT-TTF-(Spy)2. This underlines the strategy consisting in assembling dissymmetrical derivatives bearing on one hand coordinating units leading to $\mathrm{CPs}$, and, on the other hand, units prone to stacking thus promoting interdigitation. With $\mathrm{Cd}(\mathrm{NCS})_{2}$, the inorganic moieties form a $2 \mathrm{D}$ ruffled layer owing to the bridging nature of the thiocyanate anions. The heteroleptic complex coordinates the remaining apical positions of the $\mathrm{Cd}(\mathrm{II})$ cations and stack with short Au-S distances. In the case of homoleptic complex 2, a 2D CP could be obtained upon assembly with $\mathrm{Co}\left(\mathrm{N}(\mathrm{CN})_{2}\right)_{2}$. This network comprises one-dimensional $\left[\mathrm{Co}\left(\mathrm{N}(\mathrm{CN})_{2}\right]_{\propto}\right.$ pillars bridged by coordination of the four peripheral thiopyridyl groups of $\mathbf{2}$. Unfortunately, owing to the loss of solvent and hence of crystallinity, the different CPs were not further characterized for their electron conductivity or optical properties.

These networks represent, to the best of our knowledge, the first heterometallic coordination polymers based on $\mathrm{Au}(\mathrm{III})$ dithiolene complexes and transition metal cations. Future work will aim at developing other dithiolene ligands and complexes and investigate their ability to form CPs with potential conducting or optical properties. 


\section{Experimental section}

\section{Synthesis}

${ }^{1} \mathrm{H}$ - and ${ }^{13} \mathrm{C}$-NMR spectra were recorded at $25{ }^{\circ} \mathrm{C}$ on a Bruker AV500 (500 MHz) spectrometer with the deuterated solvent as the internal reference. NMR chemical shifts and $J$ values are given in parts per million (ppm) and in Hertz, respectively. Elemental analysis and mass spectrometry were performed at the Service commun d'analyses of the University of Strasbourg. Cyclic voltammetry was performed on a PARR potentiostat with ferrocene as an internal reference. UV-visible spectra were recorded on a Perkin Elmer Lambda 650S spectrophotometer. Dithiolone 3, cyclometalled complex $\mathbf{4}$ and thiocyanate salts were prepared as described. ${ }^{11 \mathrm{a}, 12,19}$ All other reagents were obtained from commercial sources and used as received.

Complex 1: Under an argon atmosphere, $5 \mathrm{mg}$ of $\mathrm{Na}(\mathrm{s})$ were added to $4 \mathrm{~mL}$ of $\mathrm{MeOH}$. Then, $54 \mathrm{mg}(0.16 \mathrm{mmol} ; 1 \mathrm{eq})$ of $\mathbf{3}$ were added. The solution was stirred for one hour and turned orange. $110 \mathrm{mg}(0.16 \mathrm{mmol} ; 1 \mathrm{eq})$ of compound $4 \mathrm{in} 3 \mathrm{~mL}$ of DMF were then added dropwise and the mixture was stirred for an additional hour. The solvents were removed under reduced pressure and the resulting solid was washed with $\mathrm{MeOH}$ and $\mathrm{Et}_{2} \mathrm{O}$ to afford the desired product as an orange solid $(44 \mathrm{mg} ; 28 \%) .{ }^{1} \mathrm{H}$ NMR $\left(500 \mathrm{MHz}, \mathrm{CD}_{2} \mathrm{Cl}_{2}\right) \delta(\mathrm{ppm})=9.10\left(\mathrm{dd},{ }^{3} J=5.4,{ }^{4} J\right.$ $=1.3,1 \mathrm{H}), 8.60\left(\mathrm{dd},{ }^{3} J=8.1,{ }^{4} \mathrm{~J}=1.3,1 \mathrm{H}\right), 8.37\left(\mathrm{ddd},{ }^{3} J=6.1,{ }^{3} J=4.5,{ }^{4} \mathrm{~J}=1.6,4 \mathrm{H}\right), 7.97(\mathrm{~d}$, $\left.{ }^{3} J=8.8,1 \mathrm{H}\right), 7.93-7.88(\mathrm{~m}, 2 \mathrm{H}), 7.81-7.75(\mathrm{~m}, 2 \mathrm{H}), 7.72\left(\mathrm{dd},{ }^{3} J=8.1,{ }^{3} J=7.3,1 \mathrm{H}\right), 7.15$ $\left(\mathrm{td},{ }^{3} J=4.5,{ }^{4} J=1.6,4 \mathrm{H}\right) .{ }^{13} \mathrm{C}$ NMR $\left(126 \mathrm{MHz}, \mathrm{CD}_{2} \mathrm{Cl}_{2}\right) \delta(\mathrm{ppm})=159.11,155.23,150.16$, $149.01,147.21,141.13,140.23,136.12,132.31,131.95,131.06,129.65,128.50,126.63$, 124.88, 123.95, 121.59, 120.81. HR-MS (ESI) $\mathrm{m} / \mathrm{z}(\mathrm{M}+\mathrm{H})^{+}$: calcd. for $\mathrm{C}_{25} \mathrm{H}_{16} \mathrm{AuN}_{3} \mathrm{~S}_{4} \mathrm{H}^{+}$: 683.9966; found 683.9984. $\lambda_{\max }(\mathrm{DMF}) / \mathrm{nm}\left(\varepsilon / \mathrm{mol}_{\mathrm{L}} \mathrm{L}^{-1} . \mathrm{cm}^{-1}\right): 282$ (6300); 314 (3900); 400 (540).

Complex $\left(\mathrm{Ph}_{4} \mathrm{P}\right) 2$ : Under inert atmosphere, $14 \mathrm{mg}$ of $\mathrm{Na}_{(\mathrm{s})}$ was added $(0.594 \mathrm{mmol} ; 2 \mathrm{eq})$ to a degassed anhydrous methanol (10 mL). Then, $200 \mathrm{mg}$ of dithiolone $3(0.594 \mathrm{mmol} ; 2 \mathrm{eq})$ in 10 $\mathrm{mL}$ of anhydrous methanol were added. After the solution became clear yellow orange, $165 \mathrm{mg}$ of $\mathrm{KAuBr}_{4}(0.297 \mathrm{mmol} ; 1 \mathrm{eq})$ in $10 \mathrm{~mL}$ of anhydrous methanol were added. After stirring for 30 minutes, the reaction mixture became dark green. Then, $112 \mathrm{mg}$ of $\left(\mathrm{PPh}_{4}\right) \mathrm{Cl}$ in $30 \mathrm{~mL}$ of distilled water $(0.297 \mathrm{mmol} ; 1 \mathrm{eq})$ was added and a green-brown precipitate formed. The solid was centrifuged and washed with $\mathrm{MeOH}$ and diethyl ether. The resulting dark green powder was then dissolved into the minimum amount of DMF and purified by diethyl ether vapor diffusion and, after $48 \mathrm{~h}$, dark green crystals of $\left(\mathrm{Ph}_{4} \mathrm{P}\right) 2$ were isolated $(74 \mathrm{mg} ; 22 \%)$. ${ }^{1} \mathrm{H}$ NMR $\left(500 \mathrm{MHz}, \mathrm{THF}_{-} \mathrm{d}^{8}\right) \delta(\mathrm{ppm})=8.25-8.22(\mathrm{~m}, 8 \mathrm{H}), 7.95-7.90(\mathrm{~m}, 6 \mathrm{H}), 7.81-7.72(\mathrm{~m}, 14 \mathrm{H})$, $7.06-7.03(\mathrm{~m}, 8 \mathrm{H}) .{ }^{13} \mathrm{C}$ NMR $\left(126 \mathrm{MHz}, \mathrm{THF}-\mathrm{d}^{8}\right) \delta(\mathrm{ppm})=150.58,150.16,136.59,135.89$, 135.81, 131.59, 131.48, 121.19. HR-MS (ESI) m/z $(\mathrm{M}+\mathrm{H})^{+}$: calcd. for $\mathrm{C}_{24} \mathrm{H}_{16} \mathrm{AuN}_{4} \mathrm{~S}_{8} \mathrm{H}^{+}$: 812.8812; found 812.8805. $\lambda_{\max }(\mathrm{DMF}) / \mathrm{nm}\left(\varepsilon / \mathrm{mol}_{\mathrm{L}} \mathrm{L}^{-1} . \mathrm{cm}^{-1}\right): 277$ (5300); 355 (2900).

CP 5: In a crystallization tube, a $\mathrm{CHCl}_{3}$ solution of $1(0.8 \mathrm{~mL}, 2.8 \mathrm{mM})$ was layered with an $\mathrm{EtOH} / \mathrm{CHCl}_{3}(0.2 \mathrm{~mL}, 1 / 1)$ buffer, then an EtOH solution of $\mathrm{Mn}(\mathrm{NCS})_{2} \bullet(4 \mathrm{Py})_{4}(0.8 \mathrm{~mL}, 4 \mathrm{mM})$ was added. Light orange crystals were obtained after few days. The combination of the crystal batches of six tubes afforded $4 \mathrm{mg}$ of CP 5 (33\%). Elemental analysis calculated for $\mathrm{C}_{52} \mathrm{H}_{32} \mathrm{Au}_{2} \mathrm{MnN}_{8} \mathrm{~S}_{10}\left(\mathrm{CHCl}_{3}\right) \mathrm{C}, 38.40 ; \mathrm{H}, 2.00 ; \mathrm{N}, 6.76$. Found: $\mathrm{C}, 38.77 ; \mathrm{H}, 2.29 ; \mathrm{N}, 6.86$. This indicates partial desolvation. IR (ATR) $v / \mathrm{cm}^{-1}: 2058(v \mathrm{CN})$. 
CP 6: In a crystallization tube, a 1,1,2,2-tetrachloroethane (TCE) solution of $\mathbf{1}(0.8 \mathrm{~mL}, 2.8$ $\mathrm{mM})$ was layered with an EtOH/TCE $(0.2 \mathrm{~mL}, 1 / 1)$ buffer and then with an EtOH solution of $\mathrm{Co}(\mathrm{NCS})_{2} \bullet(4 \mathrm{Py})_{4}(0.8 \mathrm{~mL}, 4 \mathrm{mM})$. Light orange crystals were obtained after few days. The combination of the crystal batches of six tubes afforded $4.2 \mathrm{mg}$ of CP 6 (28\%). Elemental analysis calculated for $\mathrm{C}_{52} \mathrm{H}_{32} \mathrm{Au}_{2} \mathrm{CoN}_{8} \mathrm{~S}_{10}\left(\mathrm{C}_{2} \mathrm{H}_{4} \mathrm{Cl}_{4}\right)_{4} \mathrm{C}, 32.44 ; \mathrm{H}, 2.17 ; \mathrm{N}, 5.04$. Found: $\mathrm{C}$, 33.06; H, 1.99; N, 5.52. IR (ATR) $v / \mathrm{cm}^{-1}: 2058(v \mathrm{CN})$.

CP 7: In a crystallization tube, a $\mathrm{CHCl}_{3}$ solution of $1(0.8 \mathrm{~mL}, 2.8 \mathrm{mM})$ was layered with an $\mathrm{MeOH} / \mathrm{CHCl}_{3}(0.2 \mathrm{~mL}, 1 / 1)$ buffer and then with an EtOH solution of $\mathrm{Cd}(\mathrm{NCS})_{2} \bullet(4 \mathrm{Py})_{4}(0.8$ $\mathrm{mL}, 4 \mathrm{mM}$ ). After few days, orange crystals formed. The crystal batch comprised majorly a phase that could be fully characterized owing to rapid desolvation upon exposure to air and very few crystals of 7. Elemental analysis calculated for $\mathrm{C}_{54} \mathrm{H}_{32} \mathrm{Au}_{2} \mathrm{Cd}_{2} \mathrm{~N}_{10} \mathrm{~S}_{12}$ : $\mathrm{C}, 35.55 ; \mathrm{H}$, 1.77; N, 7.68. Found: $\mathrm{C}, 32.21 ; \mathrm{H}, 1.71 ; \mathrm{N}, 6.16$. The discrepancy in the analysis results from the fact that 7 is a minor product in the crystal batch. IR (ATR) $v / \mathrm{cm}^{-1}: 2178(v \mathrm{CN})$.

CP 8: In a crystallization tube, a DMF solution of $\left(\mathrm{Ph}_{4} \mathrm{P}\right) 2(2 \mathrm{~mL}, 1.8 \mathrm{mM})$ was layered with an $\mathrm{MeOH} / \mathrm{DMF}(0.2 \mathrm{~mL}, 1 / 1)$ buffer before adding an EtOH solution of $\mathrm{Co}\left(\mathrm{N}(\mathrm{CN})_{2}\right)_{2}(0.8 \mathrm{~mL}$, $5.2 \mathrm{mM}$ ). Orange crystals were obtained after few days. The combination of the crystal batches of three tubes afforded $5 \mathrm{mg}$ of CP 8 (43\%). Elemental analysis calculated for $\mathrm{C}_{26} \mathrm{H}_{16} \mathrm{AuCoN}_{7} \mathrm{~S}_{8}$ $\left(\mathrm{CH}_{4} \mathrm{O}\right)_{4} \mathrm{C}, 33.77 ; \mathrm{H}, 3.02 ; \mathrm{N}, 9.18$. Found: C, 33.75; H, 3.38; N, 10.00. IR (ATR) $v / \mathrm{cm}^{-1}: 2176$ $(v \mathrm{CN})$.

\section{X-Ray crystallography}

Data were collected on a Bruker SMART CCD diffractometer with Mo-K $\alpha$ radiation at $173 \mathrm{~K}$ for all compounds. The structures were solved using SHELXS-97 and refined by full matrix least-squares on $F^{2}$ using SHELXL-2014 with anisotropic thermal parameters for all nonhydrogen atoms ${ }^{20}$ Hydrogen atoms were introduced at calculated positions and refined using the riding model. For CPs $\mathbf{6}$ and $\mathbf{8}$, several highly disordered solvent molecules are present in the structure but could however not be properly refined. The SQUEEZE command was used to account for the corresponding electron density. ${ }^{15}$

X-ray diffraction powder patterns were recorded at $293 \mathrm{~K}$ on a Bruker D8 diffractometer using monochromatic $\mathrm{Cu}-\mathrm{K} \alpha$ radiation with a scanning range between 4 and $40^{\circ}$ using a scan step of $0.0225 \% \mathrm{~min}$. The simulated diagrams were generated with the Mercury ${ }^{\circledR}$ software based on the single-crystal data collected at $173 \mathrm{~K}$.

\section{Conflicts of interest}

There are no conflicts to declare.

\section{Acknowledgements}

We thank the Universite de Strasbourg, the C.N.R.S., the International centre for Frontier Research in Chemistry (icFRC), the Labex CSC within the Investissement d'Avenir program 
ANR-10-IDEX-0002-02 (Ph. D. fellowship to D. B.) and the Ministère de l'Enseignement Supérieur, de la Recherche et de l'Innovation for financial support.

\section{Notes and references}

1 (a) W. Paw, S. C. Cummings, M. A. Mansour, W. B. Connick, D. K. Geiger and R. Eisenberg, Coord. Chem. Rev., 1998, 171, 125. (b) P. Cassoux, Coord. Chem. Rev., 1999, 185186, 213. (c) N. Robertson and L. Cronin, Coord. Chem. Rev., 2002, 227, 93. (d) R. Kato, Chem. Rev., 2004, 104, 5319. (e) Dithiolene chemistry, Syntheses, Properties and Applications. Prog. Inorg. Chem. Stiefel. E. I. Ed.; Wiley, NY, 2004, Vol. 52. (f) M. L. Mercuri, P. Deplano, L. Pilia, A. Serpe and F. Artizzu, Coord. Chem. Rev., 2010, 254, 1419. (g) P. Deplano, L. Pilia, D. Espa, M. L. Mercuri and A. Serpe, Coord. Chem. Rev., 2010, 254, 1434. (h) S. Rabaça and M. Almeida, Coord. Chem. Rev., 2010, 254, 1493. (i) T. Kusamoto and H. Nishihara, Coord. Chem. Rev., 2019, 380, 419. (j) F. Camerel and M. Fourmigué, Eur. J. Inorg. Chem., 2020, 508. (k) D. Fontinha, S. A. Sousa, T. S. Morais, M. Prudêncio, J. H. Leitão, Y. Le Gal, D. Lorcy, R. A. L. Silva, M. F. G. Velho, D. Belo, M. Almeida, J. F. Guerreiro, T. Pinheirog and F. Marques, Metallomics, 2020, 12, 974.

2 (a) S. Kitagawa, S. Noro and T. Nakamura, Chem. Commun., 2006, 701. (b) M. Andruh, Chem. Commun., 2007, 2565. (c) S. J. Garibay, J. R. Stork and S. M. Cohen, Prog. Inorg. Chem. 2009, 56, 335. (d) S. A. Baudron, CrystEngComm, 2010, 12, 2288. (e) A. D. Burrows, CrystEngComm, 2011, 13, 3623. (f) M. C. Das, S. Xiang, Z. Zhang, and B. Chen, Angew. Chem. Int. Ed., 2011, 50, 10510. (g) G. Kumar and R. Gupta, Chem. Soc. Rev., 2013, 24, 9403. (h) S. A. Baudron, CrystEngComm, 2016, 18, 4671. (i) S. Svrivastasa and R. Gupta, CrystEngComm, 2016, 18, 9185. (j) M. Y. Masoomi, A. Morsali, A. Dhakshinamoorthy and H. Garcia, Angew. Chem. Int. Ed., 2019, 58, 15188.

3 (a) M. Simard, D. Su, and J. D.; Wuest, J. Am. Chem. Soc., 1991, 113, 4696. (b) S. Mann, Nature, 1993, 365, 499. (c) M. W. Hosseini, Acc. Chem. Res., 2005, 38, 313. (d) M. W. Hosseini, Chem. Commun., 2005, 5825.

4 (a) X. Ribas, J. Dias, J. Morgado, K. Wurst, M. Almeida, J. Veciana and C. Rovira, CrystEngComm., 2002, 4, 564. (b) X. Ribas, J. Dias, J. Morgado, K. Wurst, E. Molins, E. Ruiz, M. Almeida, J. Veciana and C. Rovira, Chem. Eur. J., 2004, 10, 1691. (c) O. Jeannin, J. Delaunay, F. Barrière and M. Fourmigué, Inorg. Chem., 2005, 44, 9763. (d) S. A. Baudron and M. W. Hosseini, Inorg. Chem., 2006, 45, 5260. (e) E. M Weiss, C. L. Barnes and P. B. Duval, Inorg. Chem., 2006, 45, 10126. (f) R. Bolligarla and S. K. Das, CrystEngComm., 2010, 12, 3409. (g) E. Delgado, C. J Gómez-García, D. Hernández, E. Hernández, A. Martin and F. Zamora, Dalton Trans., 2016, 45, 6696. (h) O. Castillo, E. Delgado, C. J Gómez-García, D. Hernández, E. Hernández, A. Martin, J. I. Martínez and F. Zamora, Inorg. Chem., 2017, 56, 11810. (i) R. Bolligarla, G. Durgaprasad and S. K. Das, Inorg. Chim. Acta, 2019, 486, 412. (j) P. Amo-Ochoa, O. Castillo, E. Delgado, A. Gallut, E. Hernández, J. Perles and F. Zamora, CrystEngComm., 2019, 21, 957. (k) O. Castillo, E. Delgado, D. Hernández, E. Hernández, A. Martin and F. Zamora, CrystEngComm., 2019, 21, 1423.

5 (a) X. Ribas, D. Maspoch, J. Dias, J. Morgado, M. Almeida, K. Wurst, G. Vaughan, J. Veciana and C. Rovira, CrystEngComm., 2004, 6, 589. (b) A.-Y. Fu, D.-Q. Wang and D.-Z. Sun, Acta Cryst. E, 2004, 60, m1869. (c) H. Hiraga, H. Miyasaka, K. Nakata, T. Kajiwara, S. Takaishi, Y. Oshima, H. Nojiri and M. Yamashita, Inorg. Chem., 2007, 46, 9661. (d) A. 
Madalan, N. Avarvari, M. Fourmigué, R. Clérac, L. F. Chibotaru, S. Clima and M. Andruh, Inorg. Chem., 2008, 47, 940. (e) S. Takaishi, M. Hosoda, T. Kajiwara, H. Miyasaka, M. Yamashita, Y. Nakanishi, K. Yamagushi, A. Kobayashi and H. Kitagawa, Inorg. Chem., 2009, 48, 9048. (f) Y. Kobayashi, B. Jacobs, M. D. Allendorf and J. R. Long, Chem. Mater., 2010, 22, 4120. (g) V. Madhu and S. K. Das, Dalton Trans., 2011, 40, 12901. (h) V. Madhu, R. Bolligarla, I. K. Naik, R. Mekala and S. K. Das, Eur. J. Inorg. Chem., 2016, 4257. (i) M. L. Aubrey, M. T. Kapelewski, J. F. Melville, J. Oktawiec, D. Presti, L. Gagliardi and J. R. Long, J. Am. Chem. Soc., 2019, 141, 5005.

6 J. Gil-Rubio and J. Vicente, Chem. Eur. J., 2018, 24, 32.

7 (a) S. A. Baudron, N. Avarvari and P. Batail, Inorg. Chem., 2005, 44, 3380. (b) A. Ranganathan, A. El-Ghayoury, L. Zorina and P. Batail, CrystEngComm., 2010, 12, 4268. (c) Y. Le Gal, T. Roisnel, P. Auban-Senzier, T. Guizouarn and D. Lorcy, Inorg. Chem., 2014, 53, 8755. (d) S. Yokomori, A. Ueda, T. Higashino, R. Kumai, Y. Murakami and H. Mori, CrystEngComm., 2019, 21, 2940. (e) H. Hachem, N. Bellec, M. Fourmigué and D. Lorcy, Dalton Trans., 2020, 49, 6056. (f) H. Hachem, O. Jeannin, M. Fourmigué, F. Barrière and D. Lorcy, CrystEngComm, 2020, 22, 3579.

8 (a) J. T. Tunney, A. J. Blake, E. S. Davies, J. McMaster, C. Wilson and C. D. Garner, Polyhedron, 2006, 25, 591. (b) A. C. Brooks, P. Day, S. I. G. Dias, S. Rabaça, I. C. Santos, R. T. Henriques, J. D. Wallis and M. Almeida, Eur. J. Inorg. Chem., 2009, 3084. (c) S. Rabaça, A. C. Cerdeira, S. Oliveira, I. C. Santos, R. T. Henriques, L. C. J. Pereira, J. T. Coutinho and M. Almeida, Polyhedron, 2012, 39, 91. (d) S. I. G. Dias, S. Rabaça, I. C. Santos, L.C.J. Pereira, R. T. Henriques and M. Almeida, Inorg. Chem. Comm., 2012, 15, 102.

9 (a) O. J. Dautel, M. Fourmigué, E. Canadell and P. Auban-Senzier, Adv. Funct. Mat., 2002, 12, 693. (b) N. Tenn, N. Bellec, O. Jeannin, L. Piekara-Sady, P. Auban-Senzier, J. Íñiguez, E. Canadell and D. Lorcy, J. Am. Chem. Soc., 2009, 131, 16961. (c) D. G. Branzea, F. Pop, P. Auban-Senzier, R. Clérac, P. Alemany, E. Canadell and N. Avarvari, J. Am. Chem. Soc., 2016, 138, 6838. (d) Y. Le Gal, T. Roisnel, P. Auban-Senzier, N. Bellec, J. Íñiguez, E. Canadell and D. Lorcy, J. Am. Chem. Soc., 2018, 140, 6998.

10 C. Bronner and O. S. Wenger, Dalton Trans., 2011, 40, 12409.

11 (a) D. Bechu, G. Rogez, M. W. Hosseini and S. A. Baudron, New J. Chem., 2019, 43, 14291. (b) D. Bechu, L. S. Xie, N. Le Breton, S. Choua, M. Dincă, M. W. Hosseini and S. A. Baudron, Chem. Commun., 2020, 56, 2407.

12 (a) A. R. Dick, K. L. Hull and M. S. Sanford, J. Am. Chem. Soc., 2004, 126, 2300. (b) J. Serra, T. Parella and X. Ribas, Chem. Sci., 2017, 8, 946.

13 (a) M. A. Mansour, R. J. Lachicotte, H. J. Gysling and R. Eisenberg, Inorg. Chem., 1998, 37, 4625. (b) K. Kubo, M. Nakano, H. Tamura, G.-E. Matsubayashi and M. Nakamoto, J. Organomet. Chem., 2003, 669, 141. (c) K. Kubo, A. Nakao, Y. Ishii, R. Kato and G.-E. Matsubayashi, Synth. Met., 2005, 153, 425. (e) K. Kubo, A. Nakao, Y. Ishii, T. Yamamoto, M. Tamura, R. Kato, K. Yakushi and G.-E. Matsubayashi, Inorg. Chem., 2008, 47, 5495. (f) B. C. White, W. Henderson, T. S. A. Hor and B. K. Nicholson, Inorg. Chim. Acta, 2013, 394, 146. (g) A. Pintus, M. C. Aragoni, M. A. Cinellu, L. Maiore, F. Isaia, V. Lippolis, G. Orrù, E. Tuveri, 
A. Zucca and M. Arca, J. Inorg. Biochem., 2017, 170, 188. (h) H. Tang, G. C. Saunders and W. Henderson, J. Coord. Chem., 2019, 72, 2550.

14 H.-Y. Wang, Y. Wu, C. F. Leong, D. M. D’Alessandro and J.-L. Zuo, Inorg. Chem., 2015, 54, 10766.

15 A. L. Spek, PLATON, The University of Utrecht, Utrecht, The Netherlands, 1999.

16 L. S. Xie, S. S. Park, M. J. Chmiliewski, H. Liu, R. A. Kharod, L. Yang, M. G. Campbell and M. Dincă, Angew. Chem. Int. Ed., 2020, doi: 10.1002/anie.202004697.

17 (a) T. Neumann, L. S. Germann, I. Moudrakovski, R. E. Dinnebier, C. dos Santos Cunha, H. Terraschke and C. Näther, Z. Anorg. Allg. Chem., 2017, 643, 1904. (b) T. Neumann, I. Jess, C. dos Santos Cunha, H. Terraschke and C. Näther, Inorg. Chim. Acta, 2018, 478, 15.

18 (a) H.-Y. Wang, J.-Y. Ge, C. Hua, C.-Q. Jiao, Y. Wu, C. F. Leong, D. M. D’Alessandro and J.-L. Zuo, Angew. Chem. Int. Ed., 2017, 56, 5465. (b) Q. Yu, J. Su, J.-P. Ma, C. F. Leong, D. M. D'Alessandro, H.-Y. Wang, M. Kurmoo and J. L. Zuo, Cryst. Growth Des., 2019, 19, 3012.

19 C. Baer and J. Pike, J. Chem. Educ., 2010, 87, 724.

20 G. M. Sheldrick, Acta Cryst. C, 2015, 71, 3. 
Table 2 Crystallographic data for compounds 1-3 and networks 5-6.

\begin{tabular}{|c|c|c|c|c|c|}
\hline & 1 & {$\left[\mathrm{Ph}_{4} \mathrm{P}\right] 2$} & 3 & 5 & 6 \\
\hline Formula & $\mathrm{C}_{25} \mathrm{H}_{16} \mathrm{AuN}_{3} \mathrm{~S}_{4}$ & $\begin{array}{l}\mathrm{C}_{48} \mathrm{H}_{36} \mathrm{AuN}_{4} \mathrm{P} \\
\mathrm{S}_{8}\end{array}$ & $\begin{array}{l}\mathrm{C}_{13} \mathrm{H}_{8} \mathrm{AuN}_{2} \mathrm{OS} \\
4\end{array}$ & $\begin{array}{l}\mathrm{C}_{54} \mathrm{H}_{34} \mathrm{Au}_{2} \mathrm{Cl}_{6} \\
\mathrm{MnN}_{8} \mathrm{~S}_{10}\end{array}$ & $\begin{array}{l}\mathrm{C}_{52} \mathrm{H}_{32} \mathrm{Au}_{2} \mathrm{Co} \\
\mathrm{N}_{8} \mathrm{~S}_{10}\end{array}$ \\
\hline FW & 683.66 & 1153.22 & 336.45 & 1777.06 & 1542.32 \\
\hline Crystal system & Monoclinic & Monoclinic & Orthorhombic & Triclinic & Monoclinic \\
\hline Space group & $C 2 / \mathrm{c}$ & $C 2 / \mathrm{c}$ & Pnma & $P-1$ & $P 2 / \mathrm{m}$ \\
\hline$a / \AA$ & $17.0312(9)$ & $26.2783(8)$ & $6.6912(9)$ & $9.2529(4)$ & $9.6303(5)$ \\
\hline$b / \AA$ & $10.1352(9)$ & $7.3186(2)$ & $20.226(3)$ & $11.2570(5)$ & $12.2272(6)$ \\
\hline$c / \AA$ & $26.7022(15)$ & $25.1423(7)$ & $10.1274(13)$ & $17.2470(7)$ & $17.1845(8)$ \\
\hline$\alpha /^{\circ}$ & & & & $93.549(2)$ & \\
\hline$\beta /^{\circ}$ & $98.850(3)$ & $99.6630(10)$ & & $105.442(2)$ & $96.342(2)$ \\
\hline$\gamma 1^{\circ}$ & & & & $92.552(2)$ & \\
\hline$V / \AA^{3}$ & $4554.3(5)$ & $4766.8(2)$ & $1370.6(3)$ & $1724.80(13)$ & $2011.12(17)$ \\
\hline$Z$ & 8 & 4 & 4 & 1 & 1 \\
\hline$T / \mathrm{K}$ & $173(2)$ & $173(2)$ & $173(2)$ & $173(2)$ & $173(2)$ \\
\hline$\mu / \mathrm{mm}^{-1}$ & 6.848 & 3.509 & 0.687 & 4.998 & 4.133 \\
\hline Refls. coll. & 80529 & 26684 & 9721 & 132896 & 140168 \\
\hline $\begin{array}{l}\text { Ind. } \\
\left(\mathrm{R}_{\text {int }}\right)\end{array}$ & $6714(0.0591)$ & $6865(0.0411)$ & $2051(0.0556)$ & $9509(0.0401)$ & $6191(0.1547)$ \\
\hline$R_{1}(\mathrm{I}>2 \sigma(\mathrm{I}))^{\mathrm{a}}$ & 0.0293 & 0.0251 & 0.0363 & 0.0268 & 0.0782 \\
\hline$w R_{2}(\mathrm{I}>2 \sigma(\mathrm{I}))^{\mathrm{a}}$ & 0.0670 & 0.0570 & 0.0918 & 0.0658 & 0.1917 \\
\hline$R_{1}(\text { all data })^{\mathrm{a}}$ & 0.0354 & 0.0348 & 0.0495 & 0.0315 & 0.0920 \\
\hline$w R_{2}(\text { all data })^{\mathrm{a}}$ & 0.0688 & 0.0605 & 0.0990 & 0.0681 & 0.1999 \\
\hline$G O F$ & 1.088 & 1.027 & 1.043 & 1.044 & 1.157 \\
\hline
\end{tabular}


Table 3 Crystallographic data for networks 7 and $\mathbf{8}$.

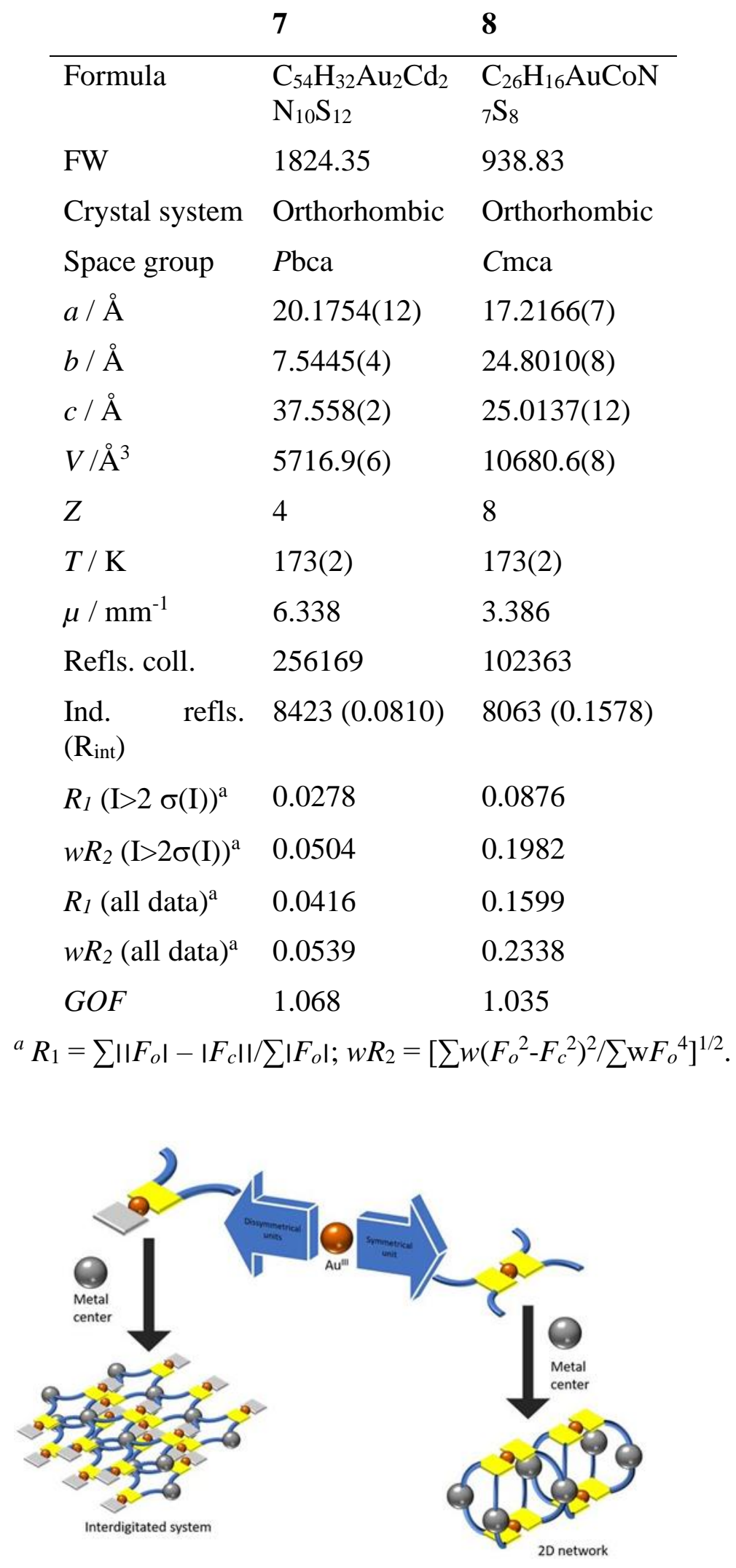

Graphical abstract Two novel hetero- and homoleptic $\mathrm{Au}(\mathrm{III})$ dithiolene complexes have been designed, synthesized, characterized and employed for the elaboration of heterometallic coordination networks. 